\title{
MEASUREMENT OF PSYCHO-EMOTIONAL CONSTRUCTS AND SELF- MANAGEMENT IN HEALTH OF PATIENTS WITH CANCER
}

\author{
MENSURAÇÃO DE CONSTRUCTOS PSICOEMOCIONAIS E DE AUTOGESTÃO \\ EM SAÚDE EM PACIENTES COM CÂNCER
}

\author{
Elisângela Muniz de SOUZA ${ }^{1}$; Ana Dalla Santana LIMA ${ }^{2}$; \\ Omar Pereira DE ALMEIDA NETO ${ }^{3}$; Fernanda Souza e Silva GARCIA ${ }^{4}$; \\ Cristiane Martins CUNHA ${ }^{5}$
}

1. Resident of the Program of Multiprofessional Residency in Health. Federal University of Uberlândia. Uberlândia-MG, Brazil; 2. Academic. Undergraduate Nursing Course. Federal University of Uberlândia. Uberlândia-MG, Brazil; 3. PhD in Health Care Cardiovascular Sciences . Professor at the Nursing Undergraduate Program. Federal University of Uberlândia, Uberlândia-MG, Brazil;

4. PhD in Sciences. University of São Paulo - Ribeirão Preto College of Nursing, Ribeirão Preto-SP, Brazil; 5. PhD in Sciences.

Professor at the Nursing Undergraduate Program. Federal University of Uberlândia, Uberlândia-MG, Brazil. cristiane.cunha@ufu.br

\begin{abstract}
The present study aimed measure self-esteem, anxiety and depression and activation scores in individuals with cancer; compare these scores according to whether or not chemotherapy was performed and verify the influence of these constructs in the self-management in health. This study is a Cross-sectional study with a quantitative approach, performed at the outpatient clinic of a school hospital. The instrument was answered by adult patients, diagnosed with cancer for at least 6 months and in outpatient follow-up. We used the Pearson correlation test and the Student $\mathrm{t}$ test in order to evaluate the variables of interest. The level of significance was 0.05 . Seventy patients participated in the study; forty six of them were women. The average age was 50.17 years $(\mathrm{SD}=11.26)$ and the average of the education level in years was 8.27 ( $\mathrm{SD}=3.73$ ). The most prevalent cancer was the breast cancer. The average score obtained by the instruments were: $32.71(\mathrm{SD}=4.64)$ for self-esteem; $6.07(\mathrm{SD}=3.84)$ for anxiety; $4.90(\mathrm{SD}=3.76)$ for depression and $64.24(\mathrm{SD}=15.21)$ for activation. We observed weak correlations of these constructs with activation ( $\mathrm{p}$ $<0.05)$ and that the use of chemotherapy did not interfere with the score of these measures $(\mathrm{p}>0.05)$. The education level presented a weak correlation with the measure of activation $(\mathrm{r}=0.240, \mathrm{p}<0.05)$, and comorbidities presented weak correlation with the measure of self-esteem $(r=-0.274, \mathrm{p}<0.05)$. In conclusion, the cancer patients presented high selfesteem, low anxiety and depression symptoms and high activation. There is a weak relationship between measures evaluated and the self-management in health.
\end{abstract}

KEYWORDS: Anxiety. Depression. Self-Esteem. Cancer. Self-Care.

\section{INTRODUCTION}

The World Health Organization (WHO) defines chronic disease as a long-term illness, usually with slow progression, which includes a set of situations that may result in disability, sequels and premature mortality. Among the chronic diseases, we highlight the oncological diseases (BRASIL, 2011; BUSSE et al., 2010).

Cancers present high morbidity and mortality worldwide, and despite the advances on its therapy, its incidence has increased exponentially (OLIVEIRA, 2013; SIEGEL 2016). Currently, it occupies the second cause of death in most of the countries of the world (HOYERT et al., 2012). The disease brings with it numerous stigmas and these refer to suffering, pain, fear of death, concern about self-image, as well as to physical, financial and social losses and to the uncertainties of success in the treatment (CARVALHO, 2007; RAMOS, 2012).

The dismemberments of cancer and of its treatment cause loss of self-esteem and emotional losses, due to the difficulty in dealing with the diagnosis and to the difficulty of living daily with the possibility of pain and finitude. Often, psychological disorders, such as depression and anxiety are present at all stages of treatment (CEOLIN, 2008). That way, it is known that the low self-esteem and the symptoms of anxiety and depression generate limitations and negatively affect the patients' health and their willingness to selfmanage their health (LEITE, 2015; SILVA et al., 2012; TERRA et al., 2013).

"Self-management" has been greatly discussed in the scientific community in our days (TOCCHI, 2015; SILVA, 2011) and is described in several ways, such as activation in health (HIBBARD et al., 2005), a concept based on the scope of "Self-management", which is considered the new global trend for addressing chronic diseases, such as cancer.

A study conducted by Cunha (2016) confirmed the theoretical relationship between the self-esteem, anxiety and depression constructs with 
health self-management in individuals with chronic diseases. So, these constructs can be highly interconnected also in cancer patients, and be indicative or predictive of better health selfmanagement in oncologic patients on the search for better outcomes in health.

In this context, it is desirable that the healthcare professionals seek strategies that evaluate the levels of self-esteem and the presence of symptoms of anxiety and depression of these patients. Strategies to reduce depressive symptoms and improve the self-esteem of patients with cancer may imply in improvement of their health status and gains in the active participation of these patients in their self-care and in their willingness and ability of self-management of their chronic condition in order to obtain better results in health.

The present study intended to measure the scores of self-esteem, anxiety and depression and activation on patients with cancer, verifying if there is a correlation between these scores and the measure of self-management in health (activation) in those patients. In addition, we compared these measures according to use, or not use, of chemotherapy and we verified the influence of some variables (age, education level, time since diagnosis, income and number of comorbidities) in the scores of such measures.

\section{MATERIAL AND METHODS}

\section{Delineation of the study and Location}

This is a cross-sectional, analytical and descriptive study with a quantitative approach, performed in the outpatient clinics of the Hospital do Cancer of the Federal University of Uberlandia, in Uberlandia City, Minas Gerais State.

\section{Participants, Procedures and Ethical Considerations}

A non-probabilistic sample for convenience, of consecutive type was formed by patients in follow-up at the oncology outpatient clinic. Were invited to participate on this study, those patients who met the previously established criteria: diagnosis of cancer for at least 6 months, age between 18 and 80 years old, preserved cognitive function - evaluated by a questionnaire that estimates discriminatory capacity and the capacity of psychic and mental orientation of this individual in time and space, according to Pfeiffer's proposal (1975). In this evaluation, the participants have to answer correctly to at least three questions, in order to be included on this study.

To the patient who was considered cognitively qualified through this evaluation, we performed the other methodological steps of this study. We adopted as exclusion criteria, the individuals with history of previous hospitalization within a period of up to one month.

After the presentation of the objectives of the study and with due clarifications, it was requested of the participants their consent in order to start the methodological protocol of the project. This research was approved by the Ethics in Research Committee. The data collection period occurred from July to September 2014. We applied a sequence of evaluative instruments: characterization of socio-demographic and clinical data, the validated versions for use in Brazil of the Rosenberg Self-Esteem Scale (RSES), "Hospital Anxiety and Depression Scale" (HADS) and Patient Activation Measure (PAM13).

\section{Description of the instruments of data collection Sociodemographic and clinical information questionnaire}

The information on socio-demographic characteristics collected was: gender, age (full years), marital status, level of education (total of years of study) and monthly family income (in Brazilian currency). The clinical data investigated were: chronic disease (self-reported), medical diagnosis (Reason for the outpatient visit, and where the interview was performed), time elapsed since the diagnosis of the chronic disease, number of morbidities described in the medical record. For the categorization of participants, according to the nature of the chronic disease, we considered the medical diagnosis that motivated the outpatient visit on the day of the interview.

\section{Version adapted to Brazilian Portuguese of the Patient Activation Measure (PAM 22)}

The instrument is composed of 22 items evaluated by an ordinal scale, with five answers options: totally disagree (1 point), disagree (2 points), agree (3 points), totally agree (4 points) and Not applicable ( 0 points). The gross score is obtained by the sum of the values indicated in the responses to the items and can range from 22 to 88 points. The gross score is later converted into an activation score (from 0 to 100 points) according to the Table of conversion of the PAM scores. The health professional or researcher will obtain the score and activation level of the individual, knowing that higher scores correspond to a higher activation for the care in health (HIBBARD et al., 2004). 


\section{Evaluation of the perceived health status by the Visual Analogue Scale (VAS)}

A visual analogue scale (VAS) of 100 millimeters was used to evaluate the perceived health status of the participants. They were instructed to indicate, in the drawn line, the position of their state of health at that time, being zero the worst state of health imaginable, and the value 100 being the best state of health.

\section{Hospital Anxiety and Depression Scale (HADS)}

The presence of symptoms of anxiety and depression was evaluated by the adapted and validated version for Brazil (BOTEGA et al., 1995) of the Hospital Anxiety and Depression Scale (HADS), composed of 14 multiple choice questions, with values ranging from zero to three. Seven of the items evaluate anxiety symptoms (HADS-Anxiety) and the other seven evaluate symptoms of depression (HADS-Depression). The sum of each subscale can range from 0 to 21 points and the higher the value, the greater the presence of the symptom evaluated.

\section{Rosenberg self-esteem scale (RSES)}

To evaluate the self-esteem, we used the Rosenberg Self-esteem Scale, on its adapted version for Brazil (AVANCI et al., 2007). It has ten items that evaluate the positive and negative feelings that the individuals have of themselves. The answers are obtained by an ordinal scale of four points, ranging from one to four. In order to obtain the total score is performed the sum of responses to the items, after the inversion of the values of the five negative items. The possible range can vary from 10 to 40 , where higher values indicate greater self-esteem.

\section{Processing and Analysis of the data}

The data collected were entered into an electronic spreadsheet (Microsoft Office Excel for Windows ${ }^{\circledR}$ ) and later transported to the IBM software, Statistical Package for the Social Sciences (SPSS) version 21.0, running in Windows ${ }^{\circledR}$ environment for the processing of the data. For all the analyses, we have adopted the significance level of 0.05 .

We performed a descriptive analysis of simple frequency for the categorical variables (gender, level of education, marital status, monthly income etc.), measures of central tendency (mean) and of variability (standard deviation) for the continuous variables.

For the measurement and analysis of the scores of the constructs: self-esteem, anxiety and depression and activation, we used the descriptive statistics (simple frequency, central tendency and variability). And for their interpretation, we used the recommendations cited by the authors in their validation studies for the Brazilian population.

To evaluate the correlation between the variables (age, level of education, time since diagnosis, income and number of comorbidities) with the measures of self-esteem, anxiety and depression and activation, we used the Pearson correlation, between the variables of interest. And to compare if there is difference between the measures of self-esteem, anxiety and depression and activation between the groups (gender, age range [18 to 30 years old, 31 to 59 years old and over 60 years old] and time since diagnosis [up to 2 years and over 2 years]) we used Student's t-test and ANOVA. We adopted the magnitude of the obtained correlations as recommended for Ajzen and Fishbein (1998): correlation values below 0.30 are of little clinical applicability, even with statistical significance; Values between 0.30 and 0.50 indicate moderate correlation and values higher than 0.50 , strong clinical correlation.

\section{RESULTS}

We approached 72 participants, 2 of them refused to participate, bringing us to a total of 70 participants. 46 of them (65.7\%) were women. The average age in years was $50.17(\mathrm{SD}=11.26)$ and all of them from the local County. The predominant level of education was high school $24(34.3 \%)$ and the average time of formal education was 8.27 years $(\mathrm{SD}=3.73)$. Almost half of the participants 32 $(45.75 \%)$ were married or living in consensual union. Most of the participants 65 (92.9\%) reported having some occupational activity and household income average of 2.04 minimum wages (Table 1).

On Table 2 we presented the clinical characteristics of the patients. We checked a variety of tumors and the most frequent type of tumor was breast cancer $23(32.8 \%)$, followed by intestinal tumor $12(17.1 \%)$ and that $58(80.86 \%)$ of all the patients were undergoing chemotherapy treatment, on that occasion. These patients presented average number of Comorbidities of 2.76 diseases $(\mathrm{DP}=$ 1.65) and average time of 1.63 years since the diagnosis $(\mathrm{SD}=1.76)$. 
Table 1. Social and Demographic Characteristics of patients with cancer.

\begin{tabular}{|c|c|c|}
\hline 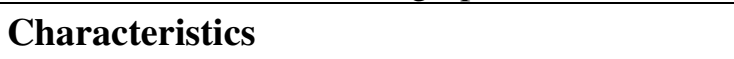 & n $(\%)$ & $\operatorname{Mean}(\mathrm{SD})^{\#}[\text { variation }]^{\mathfrak{f}}$ \\
\hline \multicolumn{3}{|l|}{ Gender } \\
\hline Female & $46(65.7)$ & \\
\hline Male & $24(34.3)$ & \\
\hline Age (in years) & & $50.17(11.26)[19-72]$ \\
\hline From 18 to 29 & $4(5.7)$ & \\
\hline From 30 to 59 & $55(78.6)$ & \\
\hline$>60$ & $11(15.7)$ & \\
\hline \multicolumn{3}{|l|}{ Origin } \\
\hline Uberlandia & $46(65.7)$ & \\
\hline Other cities of state & $24(34.3)$ & \\
\hline \multicolumn{3}{|l|}{ Level of Education } \\
\hline Elementary & $18(25.7)$ & \\
\hline Middle & $20(28.5)$ & \\
\hline High School & $24(34.3)$ & \\
\hline College & $6(8.5)$ & \\
\hline Post-graduate & $2(2.9)$ & \\
\hline Time of formal study (years) & & $8.27(3.73)[3-20]$ \\
\hline \multicolumn{3}{|l|}{ Marital Status } \\
\hline Married/consensual union & $32(45.7)$ & \\
\hline Other* & $38(54.3)$ & \\
\hline Gross Family Income (in Brazilian currency) & & $1799.81(1358.06)$ [724.00 - 8000.00] \\
\hline Up to 1000.00 & $25(35.7)$ & \\
\hline From 1000.01 to 2000.00 & $30(42.9)$ & \\
\hline Over 2000.00 & $15(21.4)$ & \\
\hline \multicolumn{3}{|l|}{ Ocupation } \\
\hline Inactive & $5(7.1)$ & \\
\hline Active & $65(92.9)$ & \\
\hline
\end{tabular}

${ }^{\#} \mathrm{SD}$ = standard deviation; $*$ single, divorced, separated or widowed $;{ }^{£}$ minimum-maximum variation

Table 2. Clinical characteristics of patients with cancer.

\begin{tabular}{lc}
\hline Characteristics & $\mathbf{n}(\%)$ \\
\hline Tumor type & \\
Breast & $23(32.8)$ \\
Intestinal & $12(17.1)$ \\
Uterine & $08(11.4)$ \\
Lung Ovário & $06(8.5)$ \\
Ovarian & $04(5.7)$ \\
Bone & $04(5.7)$ \\
lymphoma & $03(4.3)$
\end{tabular}


Other*

\section{Number of Comorbidities}

Up to 3

Over 3

Undergoing chemotherapy treatment

Yes

No

Time since diagnosis (years)

Up to 2

$53(75.7)$

Over 2

$17(24.3)$
$12(17.14)$

$10(14.2)$

$2.76(1.65)[1-7]$

49 (70.0)

$21(30.0)$

$1.63(1.76)[0.5-10]$
Regarding to the scores obtained by the measuring instruments, we verified that the patients had an average score of self-esteem that reflected high self-esteem (mean 32.71). And the scores to measure symptoms of anxiety and depression showed that these symptoms are at normal levels, equivalent to the levels of the population in general. The Activation scores demonstrated that the evaluated patients presented high level of activation (level 4), with mean of 64.24 points (Table 3).

Table 3. Total Mean Scores and standard deviations (SD) of measures of self-esteem, perceived health status, anxiety and depression and activation of patients with cancer.

\begin{tabular}{lcc}
\hline \multirow{2}{*}{ Instrument } & \multicolumn{2}{c}{ Cancer } \\
\cline { 2 - 3 } & Variation (scores) & Mean (SD) \\
\hline RSES & $22.0-40.0$ & $32.71(4.64)$ \\
HADS A & $0-18.0$ & $6.07(3.84)$ \\
HADS D & $0-17.0$ & $4.90(3.76)$ \\
PAM13 & $40.1-100.0$ & $64.24(15.21)$ \\
\hline
\end{tabular}

When evaluating if there are difference between the mean scores of the measures of selfesteem, anxiety and depression and activation, we

observed that the use, or not use, of chemotherapy does not interfere with the scores on the evaluated patients (Table 4).

Table 4. Total Mean Scores and standard deviations (SD) of measures of self-esteem, perceived health status, anxiety and depression and activation, according to whether or not chemotherapy was performed.

\begin{tabular}{lccc}
\hline Instrument & $\begin{array}{c}\text { On chemotherapy } \\
\mathbf{n = 5 8}\end{array}$ & $\begin{array}{c}\text { No chemotherapy } \\
\mathbf{n = 1 2}\end{array}$ & $\mathbf{p}$ \\
\hline RSES & $33.05(4.75)[22-40]$ & $31.36(4.03)[26-38]$ & 0.369 \\
HADS A & $6.20(4.01)[0-18]$ & $5.57(3.18)[2-11]$ & 0.391 \\
HADS D & $4.75(3.97)[0-17]$ & $5.50(2.82)[1-10]$ & 0.274 \\
PAM13 & $64.91(15.46)[41.7-100]$ & $61.54(14.35)[40.1-91.6]$ & 0.723 \\
\hline
\end{tabular}

We evaluated the reliability of the measuring instruments through the Cronbach's alpha coefficient. We verified that all the instruments presented adequate levels of reliability, as follows: PAM13 $(\alpha=0.77)$, RSES $(\alpha=0.76)$ and HADS $(\alpha$ $=0.81)$. In addition, we evaluated the validity of convergent construct between these measures, between the activation construct with the other measures. We verified that the measure of activation shows a significant theoretical relationship, from weak magnitude to moderate, with all other measures evaluated $(\mathrm{p}<0.05)$, with the following correlations: self-esteem $(\mathrm{r}=0.328)$; anxiety $(\mathrm{r}=$ 0.294); depression $(r=-0.258)$ and perceived health status $(r=0.286)$. 
When evaluating the Pearson correlation coefficients between the measures of activation, self-esteem and anxiety and depression in patients with cancer, with the variables (age, level of education, diagnosed and self-reported comorbidities, time since diagnosis and income), we verified that, only the variables, level of education and the number of comorbidities showed significant correlations. Level of education showed a weak correlation with the activation measure $(r=0.240, p$ $<0.05$ ), and the variable, number of comorbidities (diagnosed and self-reported) also presented a correlation of weak magnitude with the self-esteem measure $(\mathrm{r}=-0.274$ and 0.257 respectively, $\mathrm{p}$ $<0.05)$. Regarding the comparisons between the measures of activation, self-esteem and anxiety and depression in patients with cancer, with the variables (gender, age range and time since diagnosis), we verified that only the depression subscale of HADS showed statistical difference between the means, regarding gender and age range $(\mathrm{p}<0.05)$.

\section{DISCUSSION}

The present study measured some subjective constructs, such as scores of measures of selfesteem, anxiety and depression and of activation in a group of patients with different types of cancer, as well as it correlated and compared these measures with different social, demographic and clinical characteristics.

As for the sample, we verified a predominance of women, similar results in other studies (SILVA, 2014; GUPTA, 2008), although some studies have found a higher prevalence of cancer in men (CARVALHO 2007; MANSANOSHLOSSE, 2012; REIS, 2014). According to estimates by the National Cancer Institute (INCA) for 2017, in Brazil, it is expected that 600 thousand new cases of cancer will occur, of which more than half will occur in females and with a higher incidence for breast cancer (BRASIL, 2015). We also verified that the majority of individuals with cancer were middle-aged adults in their 50s. These results were similar to other studies in which the average age ranged from 50 to 53 years (ENDART, 2015; MIRANDA, 2013). According to INCA (2011), age remains one of the most important risk factors, with a relatively rare incidence before the age of 35 , but above this age range, this mean increases rapidly and progressively (BRASIL, 2011).

Regarding to the type of cancer, we verified that the most frequent cases were breast cancer, followed by intestinal tumor. These results vary greatly in the literature, in some studies the most common type of cancer was breast cancer (SILVA, 2014; GUPTA, 2008). Other studies have found a higher incidence of cases in the gastrointestinal system and lungs (LIMA, 2009; OLIVEIRA, 2015; MACHADO, 2009). It is important to emphasize that in addition to genetic factors, the incidence of some types of cancer is related to the geographic region and to the risk factor that the individual is exposed, besides the cultural and the eating habits (SOUZA, 2015; CASTRO, 2012).

Concerning to other social and demographic characteristics, although our study had been conducted in a public hospital, we verified the prevalence of individuals of medium level of education and medium income, with similar findings in some studies (CANGUSSI 2010; BERGEROT, 2014; SAWADA, 2009; MCCAFFREY, 2016), however other studies showed different results, with population of low income and low level of education (REIS, 2014; LEITE, 2015). Greater level of education and greater income may be beneficial for patients with cancer, since it may reflect favorably in the treatment, in a way that the patient can better understand the signs and symptoms of their illness, through active search for information about therapy and better communication with the health professionals, besides having more access to balanced and nutritious food, according to the needs of their chronic condition (ANJOS 2012; ATES, 2016; SAWADA, 2016).

In our study, we verified that the patients exhibited a medium family income, slightly higher than two minimum wages. We considered this information important, since almost all of the patients were performing labor activities, even during the time they were undergoing chemotherapy treatment. The chemotherapy treatment by itself brings with it great physical and psychological sufferings for the patient, what often prevents the performance these activities. Some studies argue that the financial need requires that these patients, even in these conditions, have to contribute with the family income, even because the expenses with the treatment compromise a lot the family budget (TAVARES, 2009; VISONÁ, 2012).

The measurement of the subjective constructs is relatively recent in the scientific community, with the development and the progressive use of measuring instruments, especially since the 90s, of the last century (PASQUALI, 2009). The instruments of measurement used in this study present all the characteristics of validity and 
reliability, in order to be used in the Brazilian population, since all were submitted to a rigorous process of cultural adaptation and psychometric validation. In the present study, we verified that all instruments presented adequate levels of reliability, with Cronbach's alpha values greater than 0.7.

With regard to the validity, we verified that these instruments showed good validity of convergent construct between the measures evaluated, since we obtained significant correlations, from low to moderate magnitude, between all the measures evaluated, which confirms the existence of theoretical relationship between the measures used, evaluated in a sample of individuals with cancer.

Regarding the scores of self-esteem obtained by the Rosenberg Self-Esteem Scale, we observed a high mean score, that reflected in high self-esteem, results consistent with some studies (GARZON, 2014; LEITE, 2015), differently other studies found opposite results (CARVALHO, 2007; ATES, 2016). Our study verified that these patients show high self-esteem, and this is justified by the fact that, despite these patients are experiencing great physical impacts, they still manage to keep that feeling, perhaps by the fight against the illness and for the will to live. High self-esteem is a factor that drives the patient to fight the disease, especially in patients with a sense of resilience and with fewer emotional disorders. Resilience empowers patients to better cope with their problems and to better manage the disease and the treatment, making use of the personal resources of confrontation and overcoming (RODRIGUES, 2012), which is very important for self-management in the health of these patients.

The literature demonstrates that the majority of patients with cancer display at different moments, some degree of symptoms of anxiety and depression (CANGUSSU, 2010; GORAYEB 2012; CARULLA, 2013; SILVA, 2014). The repercussions of cancer, that are results of its aggressive treatment, the uncertainties regarding the outcome of the illness and the social changes imposed by the illness, among other factors, make those patients highly vulnerable to psychological illness, and because of that, the symptoms of anxiety and depression are common in patients with cancer (KAMINSKA et al, 2015; BERTAN; CASTRO, 2010; SOUZA, 2013; CALEGARI, 2011). In our study, we observed that the score of symptoms of anxiety and depression in patients with cancer are at normal levels, equivalent to those of the general population. These results were consistent with some studies, (SILVA, 2014; GARZON, 2013;
SRIVASTAVA，2016; COSTA，2014) however other studies show different results (BURGESS, 2005; MEHNERT, 2008). The fact that our study have found results that identify only mild symptoms of anxiety and depression, that are compatible with the levels of the population in general, may be related with the high levels of self-esteem (and vice versa), also shown in this study. Individuals with high self-esteem tend to rely on their own potential, because they hold feelings of high self-efficacy and believe that they are the vehicle for their realization (TERRA, 2013).

The activation score demonstrated that the evaluated patients had a high level of activation (level 4), showing that these patients have a vast knowledge about their health condition, the confidence to act and the skills necessary to perform healthy behaviors and changes in their lifestyle. In this way, patients with a high level of activation are able to maintain their health and deal with their health problems, which in this specific case are problems that came as a result of the cancer. Besides, the fact that we have found in these patients, high self-esteem and low levels of anxiety and depression symptoms it is in totally agreement with our findings it is a result of the positive correlation between these constructs. Some studies, that evaluate this variable in individuals with cancer, highlighted the importance of these patients be activated to the self-management of their health (GREENE et al., 2011) and to be stimulated by the multi-professional team to this purpose, through health interventions and communication, giving them better outcomes in health (JANSEM, 2016; SMITH, 2013; MACK, 2015; DEEN, 2011).

In this research, we evaluated whether there were statistical differences between the scores obtained of the measures evaluated according to the use, or not use, of chemotherapy treatment. Our results did not find statistical differences in the scores between these two groups. This may be a reflection of the high scores of self-esteem and of the low levels of emotional disorders presented by the participants. In regard to the correlations between the measures and some variables, we verified that only the variable, level of education showed significant correlation with the measure of activation and that the variable of number of comorbidities showed a significant correlation with measure of self-esteem. Studies that analyze the associations between activation of the patient have demonstrated that patients with a higher level of education in health are more activated (SMITH, 2013; AUNG, 2015). 
Despite of this study have reached the proposed objectives, we acknowledge the existence of some limitations, that can be overcome in other studies, such as the size of our sample, the lack of a clinical intervention in order to measure the effects of interventions on this population and the lack of a more objective clinical evaluation, through the use of other clinical variables and results of propaedeutic tests or specific laboratory tests.

The present study evaluated the scores of self-esteem, anxiety and depression and of activation in a group of patients with different types of cancer and was able to respond to the proposed objectives. The found results here are evidence so that the health professionals can include the evaluation of these subjective constructs in the clinical evaluation of patients with cancer and seek strategies in order to detect and reduce symptoms of depression and improve the self-esteem of these patients. All these strategies aim for earnings in the activation of the individual with cancer, based on their self-care, and in the greater disposition and individual's aptitude for self-management of their chronic condition in order to obtain better outcomes in health.

\section{ACKNOWLEDGEMENTS}

The data used in this study come from the doctoral thesis "Patient Activation Measure (PAM): Adaptation and validation of the 22 and 13 items versions in a sample of Brazilians with chronic diseases", defended by Cristiane Martins Cunha, in the Program of Post-Graduation in Fundamental Nursing, University of São Paulo, Ribeirão Preto, Brazil, 2016.

The authors are grateful for the kindness of the author in assigning the data for the accomplishment of this manuscript. And the Coordination for the Improvement of Higher Education Personnel (CAPES) for funding, support and support.

RESUMO: O presente estudo objetivou mensurar os escores de autoestima, ansiedade e depressão e de ativação em indivíduos com câncer, comparar esses escores segundo a realização ou não de quimioterapia e verificar a influência desses constructos na autogestão em saúde. É um estudo transversal com abordagem quantitativa, realizado no ambulatório de um hospital Universitário. Pacientes adultos, com diagnóstico de câncer, há pelo menos 6 meses e em acompanhamento ambulatorial, responderam os Instrumentos. Utilizamos testes de correlação de Pearson e $\mathrm{t}$ de student para avaliar as variáveis de interesse. Nível de significância de 0,05. Participaram 70 pacientes, sendo 46 mulheres. A idade média foi 50,17 anos $(\mathrm{DP}=11,26)$ e o tempo médio de escolaridade foi 8,27 anos $(\mathrm{DP}=3,73)$. $\mathrm{O}$ tipo de câncer mais prevalente foi o de mama. Os escores médios obtidos pelos instrumentos foram: 32,71 ( $\mathrm{DP}=4,64)$ para autoestima, 6,07 $(\mathrm{DP}=3,84)$ para ansiedade, 4,90 $(\mathrm{DP}=3,76)$ para depressão e de 64,24 $(\mathrm{DP}=15,21)$ para ativação. Verificamos correlações fracas desses constructos com ativação $(\mathrm{p}<0,05)$ e que a realização ou não de quimioterapia não interferiu com as pontuações dessas medidas $(\mathrm{p}>0,05)$. A escolaridade apresentou correlação fraca com a medida de ativação ( $\mathrm{r}=0,240$, $\mathrm{p}<0,05)$, e o número de comorbidades apresentou correlação de magnitude fraca com a medida de autoestima $(r=-0,274$, p $<0,05)$. Concluímos que os pacientes com câncer apresentaram autoestima elevada, sintomas de ansiedade e depressão baixos e ativação elevado. Há uma relação fraca entre as medidas avaliadas com a autogestão em saúde.

PALAVRAS-CHAVES: Ansiedade. Depressão. Autoestima. Câncer. Autocuidado.

\section{REFERENCES}

AJZEN J, FISHBEIN M. Understanding Attitudes and Predicting Social Behavior. New Jersey: Prentice-Hall; 1998.

ANJOS, J. C.; ALAYALA. A.; HOFELMAN, D. A. Fatores associados ao câncer de mama em mulheres de uma cidade do Sul do Brasil: estudo caso-controle. Cadernos de Saúde Coletiva, Rio de Janeiro, v. 20, n. 3, p. 341-50, dez. 2012.

ATES, O.; SOYLU, C.; BABACAN, T.; SARICI, F.; KERTMEN, N.; ALLEN, D.; SERVER, A. R.;

ALTUNDAG, K. Assessment of psychosocial factors and distress in women having adjuvant endocrine therapy for breast cancer: the relationship among emotional distress and patient and treatment-related factors. [S.1]:

Springer Plus, v. 5, n. 486, 7 p. apr. 2016. 
AUNG, E.; HONS, M. D.; COLL, J. R.; WILLIAMS, G.M.; DOI, S. A. R. Association between patient activation and patient-assessed quality of care in type 2 diabetes: results of a longitudinal study. [S.1]: Health Expectations, v. 18, n. 5, p. 356-366, feb. 2015.

AVANCI, J. Q.; ASSIS, S. G.; SANTOS, N. D.; OLIVEIRA, R. V. Adaptação Transcultural de Escala de Auto-Estima para Adolescentes. Psicologia: Reflexão e Crítica. Rio Grande do Sul, v. 20, n. 3, p. 397-405, dez. 2007.

BERTAN, F. C.; CASTRO, E. K. Qualidade de vida, indicadores de ansiedade e depressão e satisfação sexual em pacientes adultos com câncer. [S.1]: Revista Salud e Sociedad, v. 1, n. 2, p. 76-88, ago. 2010.

BOTEGA, N. J.; BIO, M. R.; ZOMIGNANI, M. A.; GARCIA JUNIOR, C.; PEREIRA, W. A. Transtornos do humor em enfermaria de clínica médica e validação de escala de medida (HAD) de ansiedade e depressão.

Revista de Saúde Pública, São Paulo, v. 29, n. 5, p. 359-63, 1995.

BRASIL. Ministério da saúde. Instituto nacional de câncer (INCA). Estimativa 2016: incidência de câncer no Brasil. INCA, 2015.

BRASIL. Ministério da Saúde. Secretaria de Vigilância em Saúde. Plano de ações estratégicas para o enfrentamento das doenças crônicas não transmissíveis (DCNT) no Brasil 2011-2022. Brasília: Ministério da Saúde, 2011.

BURGESS, C.; CORNELIUS, V.; LOVE, S.; GRAHAM, J.; RICHARDS, M.; RAMIREZ, A. Depression and anxiety in women with early breast cancer: five year observational cohort study. BMJ. São Paulo, v. 330, n. 7493, p. 702, feb. 2005. https://doi.org/10.1136/bmj.38343.670868.D3

CALEGARI, E. G.; FELDENS, V. P.; SAKAE, T. M. Prevalência de sintomas depressivos em pacientes com câncer de mama submetidos à quimioterapia em um centro de referência terciário em Tubarão/ SC. [S.1]:

Arquivos Catarinenses de Medicina, v. 40, n. 3, p. 49-55, 2011.

CANGUSSU, R. O.; SOARES, T. B. C.; BARRA, A. A.; NICOLATO, R. Sintomas depressivos no câncer de mama: Inventário de Depressão de Beck - Short Form. Jornal Brasileiro de Psiquiatria, Rio de Janeiro, v. 59, n. 2, p. 106-110, mar. 2010.

CARULLA, J.; JARA, C.; MARTINEZA, C.; LEDESMAY, F.; GESTALT. Terapia. Revista IGT na Rede, v. 9, n. 16, p. 43-69, 2012.

CARVALHO, M. P.; FILHO, R. S. O.; GOMES, H. C.; VEIGA, D, F.; FERREIRAS, L. M. Autoestima em pacientes com carcinomas de pele. Revista do Colégio Brasileiro de Cirurgiões, Rio de Janeiro, v. 34, n. 6, p. 361-366, dez. 2007.

CEOLIN, V. E. S. A família frente ao diagnóstico do câncer. In: C. F. M. Hart (Org.) Câncer: Uma abordagem psicológica. Revista AGE, Porto Alegre, p. 118-128, 2008.

CUNHA, C. M. Patient Activation Measure (PAM): Adaptação e validação das versões de 22 e de 13 itens em uma amostra de brasileiros com doenças crônicas. 2016. 198 f. Tese (Doutorado em Ciências) - Curso de Pós-Graduação em Enfermagem Fundamental, Universidade de São Paulo de Ribeirão Preto, Ribeirão Preto, 2016.

DEEN, D.; LU, W. H.; ROTHSTEIN, D.; SANTANA, L.; GOLD, M. R. Asking questions: The effect of a brief intervention in community health centers on patient activation. [S.1]: Patient education and counseling. v. 84, n. 2, p. 257-60, aug. 2011. https://doi.org/10.1016/j.pec.2010.07.026 
DINI, G. M.; QUARESMA, M. R.; FERREIRA, L. M. Adaptação cultural e Validação da versão brasileira da Escala de Auto-Estima de Rosenberg. Revista da Sociedade Brasileira de Cirurgia Plástica, São Paulo, v. 9 , n. 1, p. 41-52, 2004.

GREENE, J.; HIBBARD, J. H. Why Does Patient Activation Matter? An Examination of the Relationships Between Patient Activation and Health-Related Outcomes. [S.1]: Journal of General Internal Medicine, v. 27, n. 5, p. 520-526, nov. 2011. https://doi.org/10.1007/s11606-011-1931-2

GUPTA, D.; GRUTSCH, J. F.; LIS, C. G. Comparison of Two Quality of Life Instruments for Cancer Patients: The Ferrans and Powers Quality of Life Index and the European Organisation for the Research and Treatment of Cancer Quality of Life Questionnaire C30. [S.1] Journal of the Society for Integrative Oncology. v. 6, n. 1, p. 13-18, 2008.

HIBBARD, J. H.; MAHONEY, E. R.; STOCKARD, J.; TUSLER, M. Development and Testing of a Short Form of the Patient Activation Measure. [S.1]: Health Services Research Journal. v. 40, n. 6p1, p. 1918-1930, july. 2005.

HOYERT, D. L.; JIAQUAN XU, M. D. Deaths: Preliminary Data for 2011. [S.1]: National Vital Statistics Reports, v. 61, n. 6, 51 p., out. 2012

KAMINSKA, M.; KUBIATOWSKIL, T.; CISZEWSKIL, T.; CZARNOCKIL, K. J.; STUDZINSK, M. M.; BOJAR, I.; STAROSLAWSKA, E. Evaluation of symptoms of anxiety and depression in women with breast cancer after breast amputation or conservation treated with adjuvant chemotherapy. Annals of Agricultural and Environmental Medicine, v. 22, n. 1, p. 185-189, 2015. https://doi.org/10.5604/12321966.1141392

LEITE, M. A. C.; NOGUEIRA, D. A.; TERRA, F. S. Avaliação da autoestima em pacientes oncológicos submetidos a tratamento quimioterápico. [S.1]: Revista Latino-Americana de Enfermagem, v. 23, n. 6, p. 1082-1089, nov-dez., 2015. https://doi.org/10.1590/0104-1169.0575.2652

LIMA, T. O.; BORGES, G. C. Avaliação da qualidade de vida em pacientes com câncer assistidos pelo centro de tratamento de câncer de Dourados. [S.1]: Interbio, v. 3, n. 2, p. 5-10, 2009.

McCAFFREY, N.; KAAMBWA, B.; CURROW, D. C.; RATCLIFFE, J. Health related quality of life measured using the EQ-5D-5L: South Australian. population norms. [S.1]: Health and Quality of Life Outcomes. v. 14, n. 1, p. 133, 2016 https://doi.org/10.1186/s12955-016-0537-0

MINISTÉRIO DA SAÚDE. Secretaria de Vigilância em Saúde. Departamento de Análise de Situação de Saúde. Plano de ações estratégicas para o enfrentamento das doenças crônicas não transmissíveis (DCNT) no Brasil 2011-2022. Brasília: Ministério da Saúde, 2011.

MIRANDA, T. V.; NEVES, F. M. G.; COSTA, G. N. R.; SOUZA, M. A. M. Estado Nutricional e Qualidade de Vida de Pacientes em Tratamento Quimioterápico. [S.1]: Revista Brasileira de Cancerologia, v. 59, n. 1, p. 57-64, nov. 2013

OLIVEIRA, M. C. M.; COTRIM, L.; NOVO, N.F.; JULIANO, Y.; SCHNAIDER, T. B. Autoestima, depressão e espiritualidade em pacientes submetidas à mastectomia ou quadrantectomia com linfadenectomia axilar.

Revista do Médico Residente, Curitiba, v. 15, n. 3, p. 170-180, jul./set. 2013.

PASQUALI, L. Psicometria: Teoria dos testes na psicologia e na educação. Petrópolis. Vozes, 2009. 
PFEIFFER, E. A short porTable mental status questionnaire for the assessment of organic brain deficit in elderly patients. [S.1]: AGS, v. 23, n. 10, p. 433-441, out. 1975. https://doi.org/10.1111/j.15325415.1975.tb00927.x

RAMOS, W. S. R.; SOUSA, F. S.; SANTOS, T. R.; JUNIOR, W. R. S.; FRANÇA, I. S. X.; FIGUEIREDO, G. C. A. L. Sentimentos vivenciados por mulheres acometidas por câncer de mama. [S.1]: Journal of the Health Sciences Institute, v. 30, n. 3, p. 241-248, abr. 2012.

REIS, R. H.; SCHWARTZ, E.; LIMA, L. M.; LANGE, C.; FEIJÓ, A. M.; DUARTE, J. C. Autopercepção de saúde de idosos usuários de um serviço de oncologia. [S.1]: Revista Eletrônica de Enfermagem, v. 16, n. 3, P. 612-618, jul-set. 2014. https://doi.org/10.5216/ree.v16i3.21482

RODRIGUES, F. S. S.; POLIDORI, M. M. Enfrentamento e Resiliência de Pacientes em Tratamento Quimioterápico e seus Familiares. [S.1]: Revista Brasileira de Cancerologia, v. 58, n. 4, p. 619-627, ago. 2012.

SAWADA, N. O., NICOLUSSI, A. C., DE PAULA, J. M., GARCIA-CARO, M. P., MARTI-GARCIA, C., CRUZ-QUINTANA, F. Qualidade de vida de pacientes brasileiros e espanhóis com câncer em tratamento quimioterápico: revisão integrativa da literatura. Revista Latino-Americana de Enfermagem, Ribeirão Preto, n. 24,12 p., jul. 2016.

SIEGEL, R. L.; MILLER, K. D.; JEMAL, A. Cancer Statistics, 2016. [S.1]: CA: A Cancer Journal of Clinicians, v. 66, n. 1, p. 07-30, jan. 2016.

SILVA, D. D. Evidence: Helping people help themselves. A review of the evidence considering whether it is worthwhile to support self-management. The Health Foundation, Long Acre, London WC2E 9RA, may. 2011.

SILVA, M. S.; CASTRO, E. K. Qualidade de vida e auto-imagem de pacientes com câncer de cabeça e pescoço. Universitas Psychologica, Bogotá, Colombia, v. 11, n. 11, p. 13-23, nov. 2012.

SILVA, N. M.; PIASSA, M. P.; OLIVEIRA, R. M. C.; DUARTE, M. S. Z. Depressão em Adultos Com Câncer. Ciência Atual - Revista Científica Multidisciplinar das Faculdades São José. Rio de Janeiro v. 2. n. 1. p. 02-14, 2014.

SMITH, S. G.; CURTIS, L. M.; WARDLE, J.; WAGNER, C. V.; WOLF, M. S. Skill Set or Mind Set? Associations between Health Literacy, Patient Activation and Health. [S.1]: Plos One, v. 8, n. 9, 7 p., sept. 2013.

SOUZA, B. F.; PIRES, F. H.; DEWULF, N. L. S.; INOCENTI, A.; SILVA, A. E. B. C.; MIASSO, A. I. Pacientes em uso de quimioterápicos: depressão e adesão ao tratamento. Revista da Escola de Enfermagem da USP, Ribeirão Preto, v. 47, n. 1, p. 61-67, 2013.

SOUZA, C. B.; FUSTINONI, S. M.; AMORIM, M. H. C.; ZANDONADE, E.; MATOS, J. C.; SCHIRMER, J. Estudo do tempo entre o diagnóstico e início do tratamento do câncer de mama em idosas de um hospital de referência em São Paulo, Brasil. Ciência e Saúde Coletiva, Rio de Janeiro, v. 20, n. 12, p. 3805-3816, dez. 2015

SRIVASTAVA, V.; ANSARI, M. A.; KUMAR, A.; SHAH, A. G.; MEENA, R. K.; SEVACH, P.; SINGH, O. P. Study of Anxiety and Depression among Breast Cancer Patients from North India. [S.1]: Clinical Psychiatry, v. 2, n. 1:4, 7 p., feb. 2016.

Tavares, J. S. C.; Trad, L. A. B. Families of women with breast cancer: challenges associated with care and coping resources. [S.1]: Interface - Comunicação, Saúde e Educação, v. 13,n. 29, p. 395-408, apr./june. 2009. 
TERRA, F. S.; MARZIALE, M. H. P.; ROBAZZI, M. L. C.C. Avaliação da autoestima em docentes de enfermagem de universidades pública e privada. Revista Latino-Americana de Enfermagem, Ribeirão Preto, 21(Spec): [08 telas], p. 71-78, fev. 2013.

VISONÁ, F.; PREVEDELLO, M.; SOUZA, E. N. Câncer na família: percepções de familiares. Revista de Enfermagem da UFSM, Santa Maria, v. 2, n. 1, p. 145-155, abr. 2012. 